\title{
Associative Experiment in the Study of a Sociocultural Stereotype
}

\author{
Asociacijų eksperimentas: \\ sociokultūrinio stereotipo analizè
}

SOCIOLINGUISTICS / SOCIOLINGVISTIKA

\section{Svitlana Lyubymova}

National Linguistic University of Kyiv, Ukraine

\section{Crossef http://dx.doi.org/10.5755/j01.sal.0.36.23814}

As complex phenomena of social and cultural experience, sociocultural stereotypes manifest in behavioural, material and verbal spheres. Notable advances in the study of various aspects of sociocultural stereotypes in humanities have not eliminated the necessity of their study in research paradigm of cognitive-linguistics that incorporates psycholinguistic methods within interpretative framework. An indepth study of sociocultural stereotypes requires rigorous empirical investigation of language evidence received from competent speakers in experimental situations. The experimental work provides a high level of empirical accuracy to verify emotional evaluation and pragmatic presuppositions conveyed by sociocultural stereotypes. The aim of this study was to unveil the meaning of a sociocultural stereotype flapper in contemporary culture and to model its cognitive structure on results of associative experiment. This sociocultural stereotype was chosen for its importance in changing standards of women behaviour in modern American culture. Flappers were young and daring American women, whose look and behaviour were criticised rigorously by traditionalists. An associative experiment conducted in the Lock Heaven College of Pennsylvania University showed the stereotype of flappers, though emerged in 1920s, still exists in national consciousness as a stereotypical image and a symbol of the epoch. The work contributes to the methodology of systematising experimental data in cognitive-linguistic research.

KEYWORDS: verbalised sociocultural stereotype, empirical approach, associative experiment, cognitive structure, modelling.

Implemented in scientific discourse almost a century ago, the term "stereotype" (Lippman, 1961) remains the most apt and widely used umbrella term that covers a vast area of related knowledge involved in comprehensive analysis of sociocultural stereotypes. Cognitive, semantic, emotional, and cultural nature of stereotypes was determined by Lippman in 1922. From this time on, scholars dwell on different aspects of stereotypes and process of stereotyping. Abundant works from the psychological, anthropological, psycholinguistic perspective have been devoted to the research of prevalently ethnic, gender, age, and less studied professional stereotypes. Usually based on visible features, sociocultural stereotypes are described as biased and prejudiced ideas that provoke a discriminating attitude toward stereotyped groups (Katz and Braly, 1933; Allport, 1958; Tajfel, 1981; Clark, 2014; Fiske, 2017; Hinton, 2017). Although not all sociocultural stereotypes are biased ideas of social groups,
SAL 36/2020

Associative Experiment in the Study of a Sociocultural

Stereotype

Received 07/2019

Accepted 04/2020

\section{Abstract}

\section{Introduction} and Theoretical Background

Research Journal Studies about Languages No. $36 / 2020$, pp. 85-96 ISSN 1648-2824 (print)

ISSN 2029-7203 (online) DOl.org/10.5755/j01.sal.0.36.23814 
these oversimplified notions of social world are always ambivalently perceived in the society. Sociocultural stereotypes are realised in symbols, heroes, and rituals (Hofstede et al., 2010, 7). They represent "the sets of values, attitudes, and behaviours shared by a group and passed on by learning" (Davies, 2003, p. 68). Stereotypes appear as results of categorisation, which is based on a universal human ability to save on cognitive resources. Natural languages not only instantiate but also encode culturally constructed categories encompassing the whole range of human experience (Sharifian, 2017).

In the cognitive linguistics perspective, a sociocultural stereotype is considered a verbalised unit of mental activity aimed to identify and store cumulative information about a typified image of a social group. Stereotypes are mental categories, the properties of which are easily applied to all members of a category (Geeraerts, 2006). Sociocultural stereotypes are represented in the language in the form of pragmatic predispositions and attitudes. $A$ lingua-cognitive approach to a study of stereotyping on the language basis requires empirical supplementation to analytical and descriptive methods. The necessity to use empirical methods alongside with introspection was expressed by many scholars, among them Talmy, who considers experimental methods the essential addition to introspective research as they discover the subtlest characteristics of cognitive entities irrespective of the researcher's view on the matter (Talmy, 2003). Experimental research gives an opportunity to confirm the facts gotten in reflection and observation of cultural phenomenon in discourse. In this work, it is hypothesised that a sociocultural stereotype flapper exists in the form of a visual representation of a typified image of emancipated young American women of the 1920s. Regaining its popularity nowadays, mostly due to the success of the musical "Chicago" and the film "The Great Gatsby", the image of a flapper is conditioned by visual arts. The task of the research was to make the profile of a sociocultural stereotype flapper in contemporary American culture on associative data. The experiment took place in one of American colleges. The data received from the test underwent qualitative and quantitative analysis, which follows by formal representation of cognitive structure of a sociocultural stereotype flapper.

Theoretically, this research is premised on the assertions that (1) stereotypes are an integral part of natural language because they are derived from the mechanisms simplifying categorisation of the world (Bartmiński, 2017); and (2) stereotypes are maintained and changed through the language and communication (Macrae et al., 1996; Levon, 2014).

It has been recognised that sociocultural stereotypes manifest on all levels of the language in different forms:

1 judgments about certain attributed or denied features of stereotyped objects (Quasthoff, 1978; Bartmiński, 1997);

2 rhetorical and stylistic devices (van Dijk, 1996);

3 lexical items that codify and interpret categories of the social world (Bartmiński, 1997);

4 connotations of the word that make a stereotype prominent as a "social meaning" in the definite context (Coulmas, 1981).

By the fact that stereotypes are instantiated in the language structures, the function of which to express meaning, researchers admit that the content, the pragmatic and cultural meaning of any kind of a stereotype, including a natural kind, is the subject to linguistic analysis (Labov, 1973; Putnam, 1975; Hamilton et al., 1992; Sharifian, 2001). Observation of linguistic competence in the domain of meaning enables establishing properties of a stereotype and their pragmatic value. 
The research is designed within the interpretive paradigm (Garfinkel, 1967; Taylor, 1993) that argues that the social world can only be understood from the standpoint of individuals who are participating in it. The associative experiment is an efficient tool to provide comprehensive information about a present state of a sociocultural stereotype, formed in the 1920s and still existing in American culture.

The associative experiment in linguistics (Turner, 1984; de Groot, 1989; Sharifian, 2001; Goroshko, 2005; Shepherd and Marshall, 2018) aims to register responses, conditioned by information circulating within the participants' culture. This experiment presupposes the access to respondents' consciousness, provoking the reactions to the stimulus. The experiment requires fixation of verbal reactions to the word-stimulus with following mathematical processing of results. The associative experiment registers the psychological meaning of the word (in this study, the word designating a sociocultural stereotype). Associated words acquire a new individual meaning that connects cognitive entity of the object under study with images, feelings, and ideas existing in the mind of respondents. Philosophical grounds for the experiment lie in Plato's idea that a person recalls images correlating them with each other. Thus, the connection is set between stimulus, introduced by an experimenter, and participants' response.

The physiological aspect of the experiment was described by Sechenov and Pavlov in their reflective theory of associations, according to which the terminal nervous connections, started by external stimulus, are responsible for emergence of associations (Plotnikova, 2011). From the psychological view, verbal responses to a stimulus refer to Miller's hypothesis of predictive relations of associations. Formally, the relations between a stimulus and a response are expressed in the formula "A is B, therefore A contains B" (Miller, 1974). A cognitive ability to invoke one entity as a reference point in order to establish the mental contact with another is an access to one conceived entity through another (Langacker, 2002). Thereby, it is supposed that the experimenter receives access to content of the object under study to form idea of its cognitive structure.

The famous Russian psychologist Leontyev considered the associative experiment the most objective method to discover the cultural specification of vocabulary in semantic interrelation (Leontyev, 1977). Developed in the previous century, the associative experiment has become an integral part of psycholinguistic research. Successful applications of experimental methods in psychological, sociological, and linguistic research have proved the appropriateness of the method.

Considering two accepted methods (controlled by the experimenter and free that provides spontaneous answers of respondents), a free associative experiment was chosen to conduct the research. Participants of the experiment were not limited in time and quantity of answers. The simple design of a free associative test provided freedom of expression. The participants were asked to answer the question: "What do you associate the word flapper with?". The respondents were not restricted in time or type of answers. An experiment which allows participants to react to the stimulus with any number of words that first come to their minds without any limits in formal or semantic features of response is called by Goroshko the "associative chain experiment" (Goroshko, 2005). Leontyev considered the associative chain experiment a variety of the free associative test. Following the traditions of Leontyev, the experiment described in this paper is called the free associative experiment.

The experiment was held in the College Lock Heaven of Pennsylvania University. The sample presented a group of 64 students of a nursing department. Their training did not interfere with the results of the experiment as participants were not specialised in history or culture 
Results and Discussion of the United States. The respondents were of different age (19-55), gender, and different previous training (school graduates, holders of bachelor's and master's degree). The major part of the group was represented by women (87\%) of less than 35 years of age (69\%). Two participants did not give their answers, so it was admitted that for $1 \%$ of the participants the word flapper is a lacuna of their conceptual system. It could be explained by insufficient knowledge of American history and culture. As this research focuses mainly on qualitative analysis, quantitative techniques do not include inferential statistics and measurement error.

While the methodology of the experiment has been well established, the data processing remains a disputable issue. The debatable question concerns the principles of data processing. As far back as Aristotle's classification, associations were grouped according to similarity, contrast or sequence. Traditionally the relations are subdivided into associations of contiguity in space and time, thematic attribution, similarity or contrast. Nowadays, linear typology has been recognised insufficient: it should include functional characteristics as well. Following the concept of semantic fields worked out by Trier and Porzig (Lyons, 1996), it is assumed that the associative field comprises paradigmatic and syntagmatic relations of response. The effective approach to data processing combines different ways to produce the most appropriate tool for the research. A successfully working typology of results takes into consideration the relations set between the word-stimulus and response, as well as the relations between the elements in the semantic field, created by the whole set of response. Organised around the word-stimulus, the elements of the field belong to particular themes. Paradigmatic and syntagmatic relations in the field are determined by cultural and language competence of respondents. Paradigmatic relations may reveal a latent criterion of the stimulus. Syntagmatic relations are much dependent on cultural tradition in assessment of the word-stimulus.

The complex processing of the data received from the associative experiment includes several stages of profound analysis of the experimental material. Grouping of responses takes place in: (1) the linguistic view; (2) the psycholinguistic view; and (3) the psychological view (Martinovich, 1997). In the linguistic view, the responses are classified as lexical units, word combinations, verbal phrases, and propositions. In the psychological perspective, a researcher outlines similarity and contiguity relations, which are set up with a stimulus. Psycholinguistic analysis considers speech activity of participants. As it is acknowledged, verbal associations appear on three levels: a basic level of existing associations, a level of producing reactions, and a general level of construing the associative field. The basic level is operated by mechanisms, which relate the words on the basis of contiguity, thus reflecting the relations in the real world. The basic level is represented by frames and gestalts. Creativity or automatism of responses is due to mental abilities of respondents and their approach to the task. Ready-made answers are conditioned by the cultural context: the respondents use acquired knowledge of the concepts, which are not experienced by them (Martinovich, 1997). The features attributed by respondents to a stimulus are determined by the context that "determines (a) which these attributes are and (b) what values these attributes take" (Andreou, 2017). The interpretative analysis is done with regard to linguistic properties of the received data, psycholinguistic character of participant's activity, and psychological reality of the context that conditions the appearance of the associations.

The psychological essence of the word-stimulus flapper is predetermined by a cultural value of the concept of a modern woman in American culture. The word denotes a social group of young American women of the 1920s that shattered the conventional idea about the role of women in the society. Their bald life style and fashion changed traditional standards of behaviour and beauty. As the referent disappeared, the meaning of the word is deduced from 
fiction, cinema, advertisements and other sources. The reactions mediated by the discourse constitute the contiguity associations. The dominant role of culture in associating process indicates the stereotypical character of the responses. Activated by the word-stimulus, specific knowledge of a sociocultural stereotype represents a complex cognitive structure, the high levels of which are visual, implicational and functional classes. As the cognition provides the appropriate contexts for words to specify the necessary meaning in the situation (Talmy, 2003), thus selected classes are considered the contexts in which the word operates unconsciously for the respondents. The thematic contexts highlight different assets of a sociocultural stereotype.

All verbal reactions underwent classification according to their semantic and functional meaning, relations of similarity and contiguity set up with the stimulus. Thus, I distinguish three thematic classes, which are determined by visual (Icon), implicational (Epoch), and functional (Activity) characteristics of the word under study. The major part of associations are represented by lexical units (63\%), $31 \%$ of reactions are word combinations, while predicative constructions (5\%) and propositions (1\%) are much less represented. Quantitatively, the groups are represented by $43 \%$ of Icon, $29 \%$ of Epoch, and $28 \%$ of Activity. The distinguished classes are illustrated in the tables in appendices.

Linguistically, the class Icon (Appendix A) is constituted by $51 \%$ of lexical units, $40 \%$ of word combinations, $8 \%$ of predicative constructions, and $1 \%$ of propositions. The visual class comprises the fragmental description of appearance and apparel (feathers, hats, fringes, beads, jewellery, sequins, etc.), which are in partitive relations with the word-stimulus. The class comprises partitive (48\%), descriptive (44\%), evaluative (5\%) and attributive (3\%) groups. Descriptive associations are represented mainly by word combinations that specify the fashion style of flappers. The small evaluative group of this class comprises word combinations and propositions that show the participants' attitude to the style or particular details in the image of flappers. The evaluative group manifests the ambivalence in perception of a flapper's image, thus confirming the stereotypical nature of it. In identifying the stimulus, the participants singled out definite peculiarities of the image they unconsciously collected from different sources. The reactions of the class form two types of relations: hypero-hyponomic (dresslace-sequin-necklace) and synonymic (sparkle-sequin, necklace-beads). The attributive (describing body-build) and descriptive (describing hair do, shoes, make up) groups set up paradigmatic relations with the word-stimulus. The attribute skinny is a distinctive feature of the flappers' body-build according to the responses.

The implicative class Epoch is constituted by partitive (61\%), specifying (23\%), and categorical (16\%) groups (Appendix B).

As flappers are considered a part of the historic period, associations set up partitive relations with the word stimulus. The landmark of American history, flapper, is connected with economic, political and cultural issues of the 1920s (prohibition, speak-easies, women's movement, jazz, etc.). The responses form a triple bond: stimulus (flapper) - epoch - characteristic feature. Related to this class, lexical units (72\%), word combinations (27\%), and propositions (1\%) reflect the most significant and bright fragments of the 1920s. The categorial group is based on formal similarity with the stimulus: associations gangsters and dapper men form a double bond with the stimulus flapper, which is characterised by a common grammatical meaning of an animated object and the reference to the period of the 1920s. The specifying group consists of proper names, which allude to iconic figures of the period (Betty Boop, Al Capone, Mae West, etc.) that function in the national consciousness as cultural models. Isolated responses, as war and events, seem illogical. It can be assumed that the respondents meant the First World War, the end of which is associated with emergence of flappers. 
The functional class Activity (Appendix C) is composed by defining (57\%), evaluative (17\%), attributive (13\%), and identifying (13\%) groups. Linguistically, associates of this class are the most diverse, represented by lexical units (74\%), word combinations (15\%), predicative constructions (10\%), and coordinative construction (1\%).

The descriptive group portrays the flappers' mode of life. Flappers are seen as dancers and strippers. Assessment of behaviour manifests in defining the stimulus by synonyms (hussy, rebel). The identifying group constitutes the relations of contiguity with the stimulus. Ascribed to the stimulus, features are gathered in the attributive group. Adjectives of this group are in synonymic (energetic - rowdy - fun exciting, glamor - classy) and antonymic (row$d y$, fun exciting - aloof, coy) relations with the word-stimulus. The adversative elements of coordinative construction (social but coy with men) describe flappers as freely communicating, but innocent from the viewpoint of modern standards of behaviour. The evaluative group shows the attitude of the respondents to flappers: careless, romantic, impudent, but active and free in their expression of feelings and desires.

The verbs wear, smoke, and dance, applied to the word-stimulus, elicit specific features of the stereotype through functional characteristics: flappers are considered by the respondents as trendsetters who devoted their life to earlier entertainments impossible for women. The verbs began, started, tried mark the conceptual characteristic "newness" of a flapper phenomenon in the social life of the 1920s.

Classification and grouping of associates facilitates modelling of a cognitive structure of the sociocultural stereotype flapper, the schematic representation of which is given in the following scheme.

Fig. 1

Cognitive structure of the sociocultural stereotype flapper according to the results of the associative experiment

\section{FLAPPER}

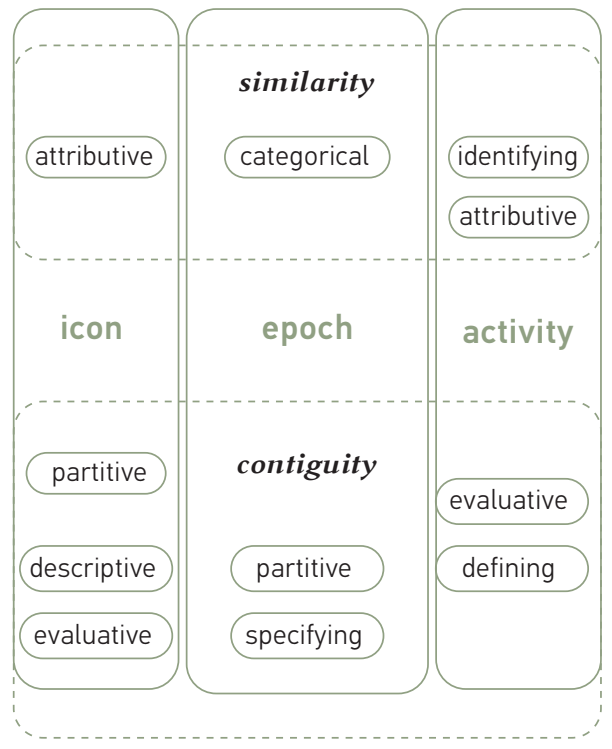


As it was shown by the experiment, the sociocultural stereotype flapper is interpreted by the participants by means of visualisation. The participants of the experiment attributed to a flapper particular qualities and functions, which they learned about indirectly. The respondents describe flappers as communicable but aloof, charming and inapproachable, fashionable and vulgar. Opposite judgements testify ambiguity of perception, which is a feature of a sociocultural stereotype. Though the social group does not exist in American society any longer, a flapper still lives in the national consciousness as a stereotypical image and a symbol of the epoch. In future, it is planned to track dynamics of changes in sociocultural stereotypes in American Media discourse.

The specification of the cognitive structure of the stereotype flapper results in the informative complex, comprising visual, implicational and functional properties connected with one another by similarity and contiguity of associations. In conclusion, it should be admitted that, rather rarely used nowadays, the method of the associative experiment is an efficient method to unveil latent information of cultural and social phenomena. Simple in design, the experiment can verify the hypothesis about the kind and the nature of sociocultural phenomena.

1 Allport, G.W. 1958. The Nature of Prejudice. Garden City, New York: Doubleday Anchor.

2 Andreou, M. 2017. Stereotype Negation in Frame Semantics. In: Glossa: A Journal of General Linguistics, 2(1): 79, pp. 1-30. http://doi. org/10.5334/gjgl.293

3 Bartmiński, J. 1997. Jetnocentrizm stereotipa: pol'skie i nemeckie studenty o svoih sosedjah [Ethnocentrism of a Stereotype: Polish and German Students about their Neighbors]. In: Slavjanovedenie, 1, pp. 12-24.Moscow: Indrik.

4 Bartmiński, J. 2017. What Does It Mean for Stereotypes to "Reside in Language"? In: Stereotypes and Linguistic Prejudices in Europe, (eds.) Dąbrowska, A., Pisarek,W. and Stickel, G., pp. 115-135. Budapest: Research Institute for Linguistics Hungarian Academy of Sciences.

5 Clark, A. 2014. Perceiving as Predicting. In: Perception and Its Modalities, (eds.) Stokes, D., Matthen, M. and Biggs, S., pp. 23-43. Oxford: Oxford University Press. https://doi.org/10.1093/ acprof:oso/9780199832798.003.0002

6 Coulmas, F. 1981. Conversational Routine. Exploration in Standardized Communication Situations and Prepatterned Speech. The Hague: Mouton.

7 Davies, E. 2003. A Goblin or a Dirty Nose? The Treatment of Culture-specific References in Translations of Harry Potter. In: The Translator, 6 , pp. 65-100. https://doi.org//10.1080/13556509. 2003.10799146
8 De Groot, A. M. 1989. Representational Aspects of Word Image Ability and Word Frequency as Assessed through Word Association. In: Journal of Experimental Psychology: Learning, Memory, and Cognition, 15(5), pp. 824-845. http://dx.doi. org/10.1037/0278-7393.15.5.824

9 Fiske, S. T. and Taylor, S. E. 2013. Social Cognition: From Brains to Culture, 2nd ed., London: SAGE.

10 Garfinkel, H. 1967. Studies in Ethnomethodology. Los Angeles: University of California.

11 Geeraerts, J. 2006. Cognitive Linguistics. Basic Readings. Berlin, New York: Walter de Gruyter. https://doi.org/10.1515/9783110199901

12 Goroshko, E. 2005. Problemy provedeniya svobodnogo associativnogo eksperimenta [Problems of Conducting Free Associatiative Experiment]. In: Izvestiya Volgogradskogo gosudarstvennogo pedagogicheskogo universiteta, 3, pp. 53-61.

13 Hamilton, D., Gibbons, P., Stroessner, S. and Sherman, J. 1992. Stereotypes and Language Use. In: Language, Interaction and Social Cognition, (eds.) Semin, G. R. and Fiedler, K., pp. 102-128. London and Newbury Park: SAGE Publications.

14 Hinton, P. R. 2017. Implicit Stereotypes and the Predictive Brain: Cognition and Culture in "Biased" Person Perception. In: Palgrave Communications, 3(17086). https://doi. org/10.1057/palcomms.2017.86 
15 Hofstede, G., Hofstede, G. J. and Minkov, M. 2010. Cultures and Organizations: Software of the Mind: Intercultural Cooperation and its Importance for Survival. New York: McGraw Hill.

16 Katz, D. and Braly, K. 1933. Racial Stereotypes of One Hundred College Students. In: Journal of Abnormal and Social Psychology, 28, pp. 280290. https://doi.org/10.1037/h0074049

17 Labov, W. 1973. Sociolinguistic Patterns. Philadelphia: University of Pennsylvania Press.

18 Langacker, R. W. 2002. Concept, Image, Symbol. The Cognitive Basis of Grammar. 2nd ed. Berlin, New York: Monton de Gruyter. https://doi. org/10.1515/9783110857733

19 Leontyev, A. 1977. Dictionary of Associative Standards of Russian Language. Moscow: Publishing House of Moscow University.

20 Levon, E. 2014. Categories, Stereotypes, and the Linguistic Perception of Sexuality. In: Language in Society, 43(5), pp. 539-566. https://doi. org/10.1017/S0047404514000554

21 Lippmann, W. 1961. Public Opinion. New York: McMillan.

22 Lyons, J. 1996. Semantics. Vol. 1. Cambridge University Press.

23 Macrae, C. Neil, Stangor, C. and Hewstone, M. 1996. Stereotypes and Stereotyping. New York: The Guilford Press.

24. Martinovich, G. 1997. Verbalnii assoziazii v assoziativnom experimente [Verbal Associations in Associative Experiment]. St. Petersburg: St. Petersburg University.

25 Miller, D. 1974. Popper's Qualitative Theory of Verisimilitude. In: British Journal for the Philosophy of Science, 25(2), pp. 165-177. https://doi.org/10.1093/bjps/25.2.166

26 26. Plotnikova, M. V. 2011. Fiziologiya vysshej nervnoj deyatelnosti i sensornyh sistem [Physiology of Higher Nervous Activity and Sensory Systems]. Tyumen: Izdatelstvo tyumenskogo gosudarstvennogo universiteta.

27 Putnam, H. 1975. The Meaning of "Meaning". In: Language, Mind and Knowledge. Minnesota
Studies in the Philosophy of Science, 7, (ed.) Gunderson, K., pp. 131-193. Minneapolis: University of Minnesota Press.

28 Quasthoff, M. U. 1978. The Uses of Stereotype in Everyday Argument: Theoretical and Empirical Aspects. In: Journal of Pragmatics, 2(1), pp. 1-48. https://doi.org/10.1016/03782166(78)90021-8

29 Taylor, G. 1993. A Theory of Practice: Hermeneutical Understanding. In: Higher Education Research and Development, 12(1), pp. 59-72. https://doi. org/10.1080/0729436930120106

30 Tajfel, H. 1981. Human Groups and Social Categories. In: Studies in Social Psychology, pp. 254-343.

31 Talmy, L. 2003. Concept Structuring Systems. In: Toward a Cognitive Semantics, 2. Cambridge: The MIT Press.

32 Turner, J. C. 1984. Social Identification and Psychological Group Formation. In: The Social Dimension: European Developments in Social Psychology, 2, (ed.) Tajfel, H., pp. 518-538. Cambridge: Cambridge University. https:// doi.org/10.1017/CB09780511759154.008

33 Sharifian, F. 2001. Association-Interpretation: A Research Technique in Cultural and Cognitive Linguistics. In: Proceedings of the 6th Annual Round Table of the Centre for Applied Language and Literacy Research. Perth: Edith Cowan University.

34 Sharifian, F. 2017. Cultural Linguistics. Cultural Conceptualisations and Language. Amsterdam, Philadelphia: John Benjamins Publishing Company. https://doi. org/10.1075/clscc.8

35 Shepherd, H. and Marshall E. A. 2018. The Implicit Activation Mechanism of Culture: A Survey Experiment on Associations with Childbearing. In: Poetics, 69, pp. 1-14. https:// doi.org/10.1016/j.poetic.2018.07.001

36 Van Dijk, T. A. (1996). Discourse, Racism and Ideology. La Laguna: RCEI Editions. 
Total reactions: 94

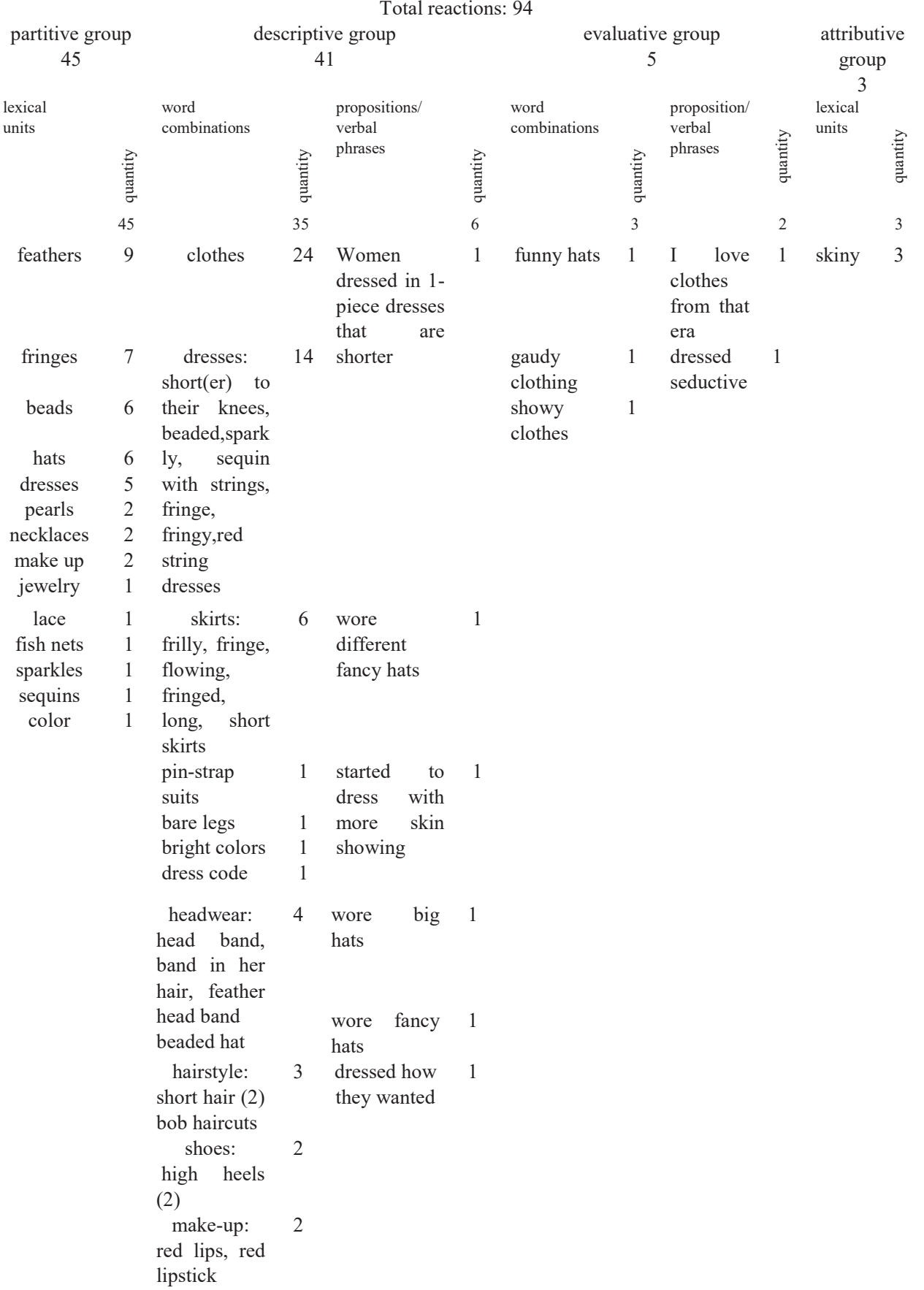

partitive group

45

feathers

9 clothes

fringes

beads

hats

dresses

pearls

necklaces

make up

jewelry

lace

fish nets

sparkles

sequins

color

To

41

14 shorter short(er) to

6 their knees, beaded,spark

6 ly, sequin

with strings,

fringe,

fringy,red

2 string

1 dresses

1 skirts:

1 frilly, fringe,

1 flowing,

1 fringed,

1 long, short

skirts

pin-strap

suits

bare legs

bright colors

dress code

headwear: 4 wore big 1

head band,

band in her

hair, feather

head band

beaded hat

hairstyle:

short hair (2)

bob haircuts

shoes: 2

high heels

(2)

make-up:

red lips, red

lipstick

evaluative group

5

propositions

verbal

phrases

छ

35

24 Women

dressed in 1-

piece dresses
that are

14 shorte

(n)

word proposition

combinations

verbal

phrases

funny hats

I love

from that

era

gaudy

showy

clothes

different

fancy hats

1

units

苝喜

seductive

Apendices

Appendix A

Associates of the class

"Icon" in figures 
Appendix B

Associates of the class "Epoch" in figures

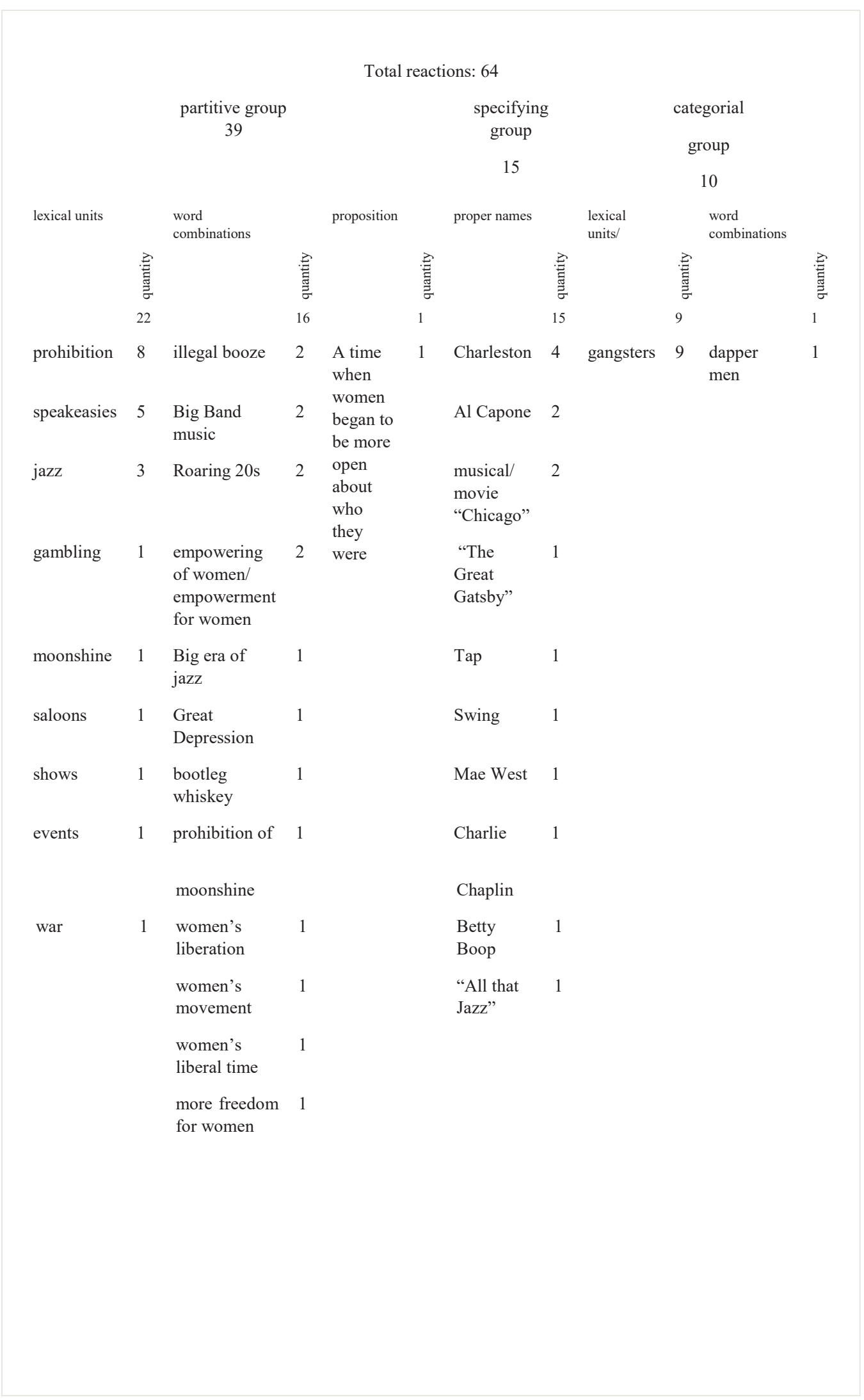


Total reactions: 60

Appendix C Associates of the class "Activity" in figures defining group

34

lexical

units

filtered
cigarettes

alcohol 2 long black 1 cigarette holder

partying $1 \begin{array}{r}\text { constant } \\ \text { cigarette }\end{array}$

beer 1 night clubs 1

gin 1 city life 1

bars 1

clubs $\quad 1$ attributive group

8

lexical units

coordinative construction

恚

7

energetic 1

social, but 1

coy

men

fun exciting 1

glamor 1

classy 1

rowdy 1

immodest 1

aloof evaluative group

10

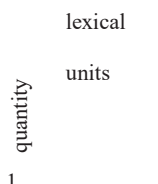

1

went to 1 fun 3

high

class

parties

easier way $1 \quad$ smoking cool $\quad 1$

of life

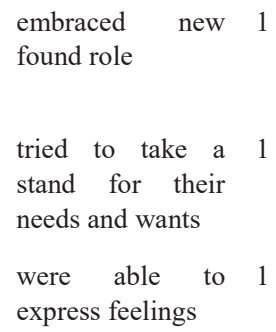

identifying group

8

lexical units

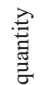

总

dancer(s) 5

hussy 1

rebel 1 


\section{Santrauka}

\section{Svitlana Lyubymova. Asociacijų eksperimentas: sociokultūrinio stereotipo analizè}

Sociokultūriniai stereotipai, kaip sudètingas socialinès ir kultūrinès patirties fenomenas, pasireiškia materialiniais ir žodiniais ženklais bei elgesio bruožais. Nepaisant to, jog humanitarinių mokslu srityje jau yra atlikta reikšmingu sociokultūriniu stereotipu aspektų tyrimu, taip pat svarbu juos išanalizuoti kognityvinès kalbotyros kontekste, taikant psicholingvistinius metodus. Išsamiems sociokultūriniu stereotipu tyrimams reikalinga tikslinga eksperimentiniu situaciju ir gautu kalbiniu irodymu analizè. Eksperimentai suteikia ypač tikslius empirinius duomenis, leidžiančius ivertinti emocini grižtamaji ryši ir sociokultūrinių stereotipu perteikiamas pragmatines presupozicijas. Šio tyrimo tikslas yra atskleisti sociokultūrinio stereotipo „flapper“ (liet. „lengvabūdè“) reikšmę šiuolaikinèje kultūroje ir, remiantis asociaciju eksperimento rezultatais, parengti šio stereotipo kognityvinès struktūros modeli. Minètasis stereotipas pasirinktas dèl jo svarbos analizuojant besikeičiančius moteru elgesio standartus moderniojoje amerikiečiu kultūroje. „Flappers“ vadinamos jaunos ir drąsios amerikietès, kurių elgesys buvo nuolat kritikuojamas tradicinių elgesio standartų šalininkų. Lock Haveno universitete, Pensilvanijos valstijoje atlikto asociaciju eksperimento rezultatai rodo, jog XX a. 3-ajame dešimtmetyje atsiradęs „flapper“ stereotipas vis dar yra nacionalinès savimonès dalis, atspindinti stereotipini ivaizdi ir tapusi epochos simboliu. Šiuo darbu prisidedama prie kognityvinès kalbotyros tyrimu atlikimo metu surinktų eksperimentinių duomenų sisteminimo.

\section{About the} Author

\section{Svitlana Lyubymova}

PhD in Philology, Associated professor, Post-doctoral student at the National Linguistic University of Kyiv, Ukraine

\section{Research interests}

Cognitive semantics, psycholinguistics, media studies

\section{Address}

Serednefontanska str. 30/1, 215 fl., Odessa, 65039, Ukraine

\section{E-mail}

elurus2006@gmail.com 